\title{
The decline of academic bilingualism in South Africa - a case study
}

\author{
Lloyd Hill ${ }^{1}$
}

\begin{abstract}
Language policies in South African higher education were formalized between 2000 and 2002, just prior to a major restructuring of the higher education system. During this period institutions of higher learning were expected to formulate both a language policy and a detailed language plan. National policies on language in education are intended to substantiate the constitutional commitment to using and developing the eleven official languages. Gaps between official commitments to 'multilingualism' and actual language practices are nevertheless evident at national and institutional levels. In this article I explore the concepts "bilingual university" and "academic bilingualism", as a prelude to a contextualized discussion of the decline of English-Afrikaans bilingualism at the University of Port Elizabeth (which after the January 2005 merger with the PE Technikon, became part of the Nelson Mandela Metropolitan University). I explore the emergence of a gap between formal policy pronouncements and actual institutional practices. I then situate this local trend within the wider context of post-1994 political and socio-economic changes and the emergence of a new official discourse on 'multilingualism.' I explain the ostensive shift from a 'dual medium' to a 'multilingual' policy at UPE in terms of broader trends and contradictions in the national field of higher education. The article employs a theoretical framework, which - drawing on the work of Bourdieu - seeks to (a) situate the case within a wider national field of higher education, and (b) theorise 'academic bilingualism' as form of cultural capital within this field. In terms of this framework, the analysis of the case raises specific questions about current institutional language policies in South Africa and more general questions about the nature of bilingualism in higher education.
\end{abstract}

\section{Introduction}

Language policies in higher education have been subjected to particular academic scrutiny in recent years. The epicentre of this trend is Europe, where the Bologna Process is reshaping the higher education landscape and - as a consequence - raising concerns about the future academic status of languages in the emerging European Higher Education Area (EHEA). Beginning in 2000, a series of European conferences has stimulated debate on the nature of 'bilingual' and 'multilingual' universities (van der Walt \& Brink 2005). During the last decade a relatively small literature on bilingual and multilingual universities has emerged. Particular attention has been given to the comparative analysis of bilingual universities, focusing on historical contexts, institutional missions and distinctive institutional features.

\footnotetext{
${ }^{1}$ Department of Sociology, University of Stellenbosch (email: $\|$ loydhill@sun.ac.za). This is a post-print version of an article published in Language Policy 8(4) (October 2009), pp. 327349.
} 
In South Africa this new academic discourse on 'multilingual universities' has resonated with higher education scholars and policy makers, who are under pressure to produce institutional responses to the post-1994 constitutional commitment to developing the eleven official languages. ${ }^{2}$ Language policies in South African higher education were formalized between 2000 and 2002. This occurred just prior to a major restructuring of the higher education system, in which a series of mergers reduced the number of tertiary institutions from 36 to 23. In terms of national language policy, institutions of higher learning were expected to "promote multilingualism" by means of a language policy and a more detailed language plan. ${ }^{3}$

Gaps between official commitments to 'multilingualism' and actual language practices are nevertheless evident at national and institutional levels. A growing domestic literature on language policy and language in education has consequently sought to explore the problems associated with formulating and implementing language policies. This literature includes a number of articles on language policies and practices at specific universities. In recent years a number of South African writers have drawn on the emerging international literature on university language policies and bilingual universities.

The distinction between 'bilingual' and 'multilingual' universities is not well theorized in the South African context, and this aggravates attempts to address the language policy gap referred to previously. This article therefore begins with a conceptual analysis of 'academic bilingualism', which is defined in terms of stratified bilingual practices located both within a given institution and within the broader environment. This is followed by a case study of academic bilingualism in South Africa, which focuses specifically on the recent decline of English-Afrikaans bilingualism at the University of Port Elizabeth (UPE: which now forms part of the Nelson Mandela Metropolitan University). In the aftermath of the 1994 political transition, UPE and a number of other universities adopted multilingual language policies, but these policies tend to belie a widespread shift to English in the various university domains. I argue that trends evident at the University of Port Elizabeth were indicative of a more widespread decline of bilingualism within the national field of higher education. This trend is explained in terms of the declining status of Afrikaans as a form of cultural capital, both within the field of higher education and more generally in the emerging post-apartheid political economy.

A particular effort has been made to situate the UPE case study within the context of the historical development and decline of a national bilingual education system. The relatively rapid rise and decline of bilingualism at this institution must be understood against this background. It should also be

\footnotetext{
${ }^{2}$ Section 29(2) of the 1996 Constitution reads as follows: "Everyone has the right to receive education in the official language or languages of their choice in public educational institutions where that education is reasonably practicable. In order to ensure the effective access to, and implementation of, this right, the state must consider all reasonable educational alternatives, including single medium institutions, taking into account - (a) equity; (b) practicability; and (c) the need to redress the results of past racially discriminatory laws and practices."

${ }^{3}$ Higher education institutions were expected to submit language policies and "three year rolling plans" by 31 March 2003. See Language Policy for Higher Education, Ministry of Education, November 2002, sections 18.3 and 20.
} 
noted that that the UPE case fits a broader pattern in the literature on bilingual universities: the predominance of European languages ${ }^{4}$ in bilingual combination at university level. The case study is therefore intended to contribute towards a more general reflection on the difficulties associated with the development and maintenance of academic bilingualism in developing countries. It is therefore hoped that the case study will be of interest not just to those with concerned with bilingual universities, but also to readers with a more general interest in bilingual education and language planning.

\section{The bilingual university as an institutional phenomenon}

The terms 'bilingual university' and 'multilingual university' have become increasingly prevalent in the literature on language policy. Recent interest dates from a UNESCO-sponsored conference on 'The Bilingual University Its Origins, Mission and Functioning', held at the European Centre for Higher Education, Bucharest, in 2000. This was followed by an international conference on 'Multilingual Universities - Practice and Standard', which was hosted by the University of Fribourg in September 2003 (van der Walt \& Brink 2005). In September 2005 the University of Helsinki hosted a conference on 'Bi- and Multilingual Universities - Challenges and future prospects." The most conspicuous issue distinguishing these two concepts is the range of institutions that they encapsulate: the narrowly defined term "bilingual university" covers a handful of universities worldwide ${ }^{6}$, while the loosely defined concept of "multilingual university" would include most universities. Purser (2000) notes that

if it is almost universal practice in higher education that more than one language be utilized in teaching and research - with the quite clear dominance of English - a unique formal structure exists - the bilingual university - about which little is known.

The term "bilingual university" is typically used to cover a relatively small number of institutions that share a number of general features. In the context of higher education 'bilingualism' refers to a range of communicative practices, which can be categorised in a number of domains: teaching; learning; research; administration; writing and other presentations; service acts; and governance within the wider university context (Jernudd 2002).

The discussion that follows is built around a broad conceptual distinction between 'internal' or intra-institutional features and 'external' or environmental features associated with bilingual universities. In the discussion of internal practices particular attention is given to teaching, learning and administration,

\footnotetext{
${ }^{4}$ Here 'European languages' is a geographical term, i.e. including, but not restricted to IndoEuropean languages.

${ }^{5}$ http://www.helsinki.fi/news/archive/7-2005/6-10-22-47 (accessed 15 January 2009)

6 These include the University of Friburg (Switzerland), Free University of Bolzano (Italy), European University Viadrina (Germany), University of Wales, Aberystwyth (UK), National University of Ireland, Galway (Ireland), University of Helsinki (Finland), University of Barcelona (Spain), University of Ottawa (Canada), University of Puerto Rico (Puerto Rico) and the Chinese University of Hong Kong (Anckar 2000; Beillard 2000; Langner \& Imbach 2000; Purser 2000; Jernudd 2002; van der Walt \& Brink 2005).
} 
as these are the domains in which the distinctive features of bilingual universities are most clearly manifested. In these domains two characteristics - commonly cited as definitive in the literature - are particularly evident: a bilingual mission or vocation; and a bilingual teaching infrastructure.

A number of writers have noted the normative aspect in their descriptions of institutional bilingualism, the essence of which is a formal institutional commitment to the use of two languages as functionally equivalent media for the purposes of administration, teaching and - often to a much lesser extent research. Thus Langer and Imbach (2000) refer to the 'bilingual vocation' of the university, while Brink (van der Walt \& Brink 2005; Brink 2006) refers to the 'language conscious institution.' This vocation is manifested, in the first instance, in a commitment to using two languages for administrative and communicative purposes. Beyond these formal channels, the bilingual vocation is manifested in a commitment to developing and sustaining two languages as academic media in the elevated educational domains of the university.

A commitment to functionally equivalent undergraduate teaching in two languages would appear to be the minimum indicator of a bilingual vocation in the literature on bilingual universities. This commitment places demands on the individual language competencies of both staff and students. A key distinction is commonly made between two types of language criteria that follow from this commitment: bilingualism as a condition and bilingualism as an outcome (du Plessis 2006). In practice many bilingual institutions are implicitly or explicitly committed to both, and variations in the commitment to these goals reflect the contrasting environments in which these universities are located. Thus, the University of Fribourg provides an example of a particularly strong commitment to bilingualism as valued outcome - certifying French-German academic bilingualism by means of its 'Bilingualism-plus' programme. The broader context of compulsory exposure to both languages in canton schools nevertheless ensures that a minimum level of FrenchGerman bilingualism is a condition of entry for most students (Brink 2006).

In terms of teaching infrastructure, the commitment to functionally equivalent bilingual instruction is typically manifested in two modes of teaching at bilingual universities. The term 'dual medium instruction' describes an institutional context in which all students are instructed in both languages, and which therefore assumes a minimum level of bilingual capacity on the part of students. Parallel medium instruction involves the use of two distinct but equivalent teaching streams. Here individual bilingualism is not assumed as a condition of entry (Beillard 2000; Langner \& Imbach 2000; du Plessis 2006).

The institutionalization of these two modes of teaching is premised on the availability of both languages as resources for learning and teaching. While bilingual universities produce bilingual learning and teaching materials, they are also invariably dependent of the availability of language resources in their immediate environment. The bilingual vocation is therefore premised on the production and consumption of academic bilingualism in a regional or national political economy. 


\section{The political economy of academic bilingualism}

Beyond the formal commitment to two academic languages, the realization of actual bilingual university forms is difficult to classify, as the institutionalization of bilingualism extends beyond the geographical boundaries of specific institutions. It is noteworthy that most of the language pairs referred to above (and listed in footnote 2) are either Indo-European or situated in Europe. Most of the universities accounted for in the literature are also public institutions, and in many cases the bilingual mandate is codified in legislation. Purser (2000) notes that "bilingual institutions are the rare exceptions to the rule of monolingualism within given nation-states."

They are, however, exceptions that tend to prove - or rather sustain - the rule of national monolingualism, as they institutionalize a sociolinguistic compromise that draws on the cultural resources produced by large monolingual political economies. Bilingual universities are invariable built on an institutional commitment to the sustained development of two standardized national languages, which are both capable of serving as media of instruction in higher education. The creation and 'implementation' of the standard (Haugen 1983) are expensive processes and a number of writers have noted that bilingual universities are considerably more costly to run than their monolingual counterparts (Purser 2000; van der Walt \& Brink 2005). The rationale for bilingualism is therefore 'political and social' (Purser 2000), which is to say based on a political compromise and a cultural cost-benefit analysis that is deemed to justify the added material expenditure.

A better understanding of the social costs associated with bilingualism at this level requires a more detailed elaboration of the concepts 'medium of instruction' and - by extension - 'academic bilingualism.' To this end the work of Pierre Bourdieu $(1986 ; 1991)$ is particularly useful, as it demonstrates how the standard language - taken for granted as the medium of tertiary instruction - is socially inscribed in a broader national education system, which is at least partially constitutive of the wider political economy. The number of languages amenable for use in higher education is small precisely because the medium of instruction exists not just as a linguistic or communicative competence, but also as a scarce form of cultural capital.

Bourdieu's work is premised on a broad distinction between material and symbolic (or cultural) processes of accumulation, which generate two broad species of capital (Wacqant 1989). Cultural capital is further elaborated in terms of three subtypes. My treatment of the concept 'medium of instruction' will therefore draw on Bourdieu's (1986) conceptualization of cultural capital in terms of three manifestations or states:

a Embodied state: symbolic capital is manifested in an embodied state in the form of cultivated dispositions, which are acquired through socialization. Socialization is the process of developing an appreciation of cultural goods, which can only be 'consumed' by apprehending their meaning. In higher education the most obvious form of embodied disposition is the ability to read and write - to decode and code - in both the spoken and written modes of the designated medium of instruction, but more subtle 
predispositions - such as the ability to navigate a library or use a computer - are typically taken for granted by an enrolling institution.

- Objectified state: cultural capital can also be objectified in the form of books, audio-visual materials, instruments, works of art, etc. Objectified cultural capital is transmissible in material form, but its appreciation or "consumption" requires specialized cultural abilities or embodied capital. Cultural goods can therefore be appropriated both materially and symbolically. Bourdieu explains the relative autonomy of language in terms of the tendency for cultural capital in its objectified state to present itself as an autonomous, coherent universe. This is most obviously the case in the elevated and abstract domains of a university, where objectified resources are the most obvious indicator of language inequality. Hence the claim that "English is the language of science; in no other language is so much educational material available as in English" (Brink 2006).

- Institutionalized state: cultural capital exists in institutionalized form when it is manifested in the growth of a system of educational credentials. Academic qualifications represent the legal certification of a competence. To the extent that they are guaranteed by an institution or the legally inscribed conventions of a field, they represent a form of cultural capital that has relative autonomy vis-à-vis its bearers and vis-à-vis the material capital that they possesses at a given moment in time (Bourdieu 1986).

'Field' is the key spatial metaphor in Bourdieu's work. Cultural fields are structured spaces organised around specific combinations of capital. 'Field' functions as a more inclusive concept than 'market' to the extent that it suggests rank and hierarchy as well as exchange relations between producers and consumers (Swartz 1997). This concept provides a particularly useful tool for the analysis of recent changes in the South African higher education system.

\section{The post-1910 bilingual field of higher education}

This brief historical overview of the history of bilingualism in South African higher education serves to contextualize the subsequent discussion of the case study and the analysis of more general post-1994 university language trends. This history can be summarized in terms of four broad periods:

a 1858 - 1918: The emergence of a monolingual English field centred on the University of the Cape of Good Hope in Cape Town;

- 1918 - 1959: The emergence of a bilingual English-Afrikaans field, following the establishment of the Universities of Cape Town and Stellenbosch as autonomous teaching universities, and the University of South Africa (in Pretoria) as an examining and certifying institution.

- 1959 - 1994: The attempt to extend apartheid into higher education and the associated creation of 'ethnic' universities in Cape Town, Durban and the nominally independent 'homelands'.

a 1994 - present: The post-apartheid transformation of the higher education system.

Higher education in South Africa can be traced back to the Board of Public Examiners in Literature and Science (BPELS), which was established in 1858. 
The Board provided a structure for academic accreditation that would eventually be extended to the other three colonies in the region. The first South African university - the University of the Cape of Good Hope - was established in 1873, replacing the BPELS. In 1874 a higher education act was passed by the Cape Parliament, which provided the framework for a new colonial higher education system (Boucher 1973). The act made provision for tertiary education at elite high schools, which were subsequently designated 'colleges.' These colleges were responsible for preparing students - in English - for the examinations of the new university. In 1875 the University Extension Act granted the University the right to operate beyond the borders of the Cape Colony. This extended the field of higher education into the two Boer Republics and the second British colony of Natal. The University of the Cape of Good Hope therefore served as the blueprint for a national university system after the unification of the state in 1910.

The undisputed status of English in higher education before 1910 can be attributed, firstly, to the extremely elite status of higher education (even within the narrow confines of the white English-speaking population) and secondly, to the diffuse nature of emerging nationalist sentiment within the Cape Dutch/Afrikaans speaking communities. With the establishment of the Union of South Africa the Cape University would undergo two fundamental changes between 1910 and $1916^{7}$ - the year in which it became known as the University of South Africa (UNISA). Firstly, it would cede its monopoly over the field of higher education accreditation, following the establishment of the University of Cape Town and the University of Stellenbosch as autonomous teaching universities. Secondly, the national accrediting university was relocated to Pretoria, where the political power of Afrikaans speakers increasingly brought the issue of language to the fore (Boucher 1973). With the rise of Afrikaner nationalism after 1910, Afrikaans would develop and gradually challenge the status of English as the dominant medium of higher education.

${ }^{7}$ The University Acts were passed in 1916, but implemented in 1918. 
In 1910 Dutch was established as an official language alongside English in the constitution of the Union of South Africa. The relevant section reads as follows:

Both the English and Dutch languages shall be official languages of the Union and shall be treated on a footing of equality and possess and enjoy freedom, rights and privileges.

Establishing 'equality' required considerably more than the stroke of a pen, and this posed particular problems in the field of education. The written Dutch standard taught in schools at this time did not correspond with the spoken language of the vast majority of "Dutch" speakers (Hartshorne 1987). During the First World War Afrikaans began to replace Dutch in schools and colleges.

In 1925 Afrikaans was subsumed under Dutch - and thereby recognised as an official language. The development of Afrikaans as a medium of instruction - first in schools and subsequently at universities - therefore involved not just the development of terminology, but the appropriation and promotion of a particular written and spoken dialect for educational purposes. This involved contestation throughout the field of education, not just between English speakers and Dutch speakers, but also within Dutch/Afrikaans speaking communities.

The struggle to develop Afrikaans as an educational medium therefore involved a double movement: a relatively 'natural' and technical effort to distinguish the new standard from its European counterpart and a more overtly political process of appropriating public educational space, which had 
previously been the exclusive preserve of English. During the 1930s, as Afrikaner nationalists sought to elevate the status of Afrikaans relative to English, the principle of mother-tongue instruction was invoked to motivate the preference for monolingual schools. Where this was not feasible, parallel medium instruction was preferred over dual medium instruction, as it was considered better suited to developing educational capacity and autonomy in Afrikaans. This represented a break with government policy during the first two decades of Union. Afrikaner nationalists were highly suspicious of Prime Minister Jan Smuts' attempt to implement dual medium instruction in South African schools. Smuts was no doubt positively disposed to bilingualism by his secondary and tertiary experiences in Stellenbosch. He became a firm advocate of the educational value of bilingualism, specifically

Hertzog's idea of dual-medium instruction, that is, the use of the second language not merely as a subject learned from text-books, but as a medium for teaching various subjects, such as history, as in Paul Roos's school at Stellenbosch (cited in Scholtz 1984).

An inverse logic subsequently applied to Afrikaner nationalist attempts to develop Afrikaans within the sphere of higher education. Here, as du Plessis (2006) has noted, parallel medium institutions were not encouraged. This can be explained in terms of costs and the difficulties associated with the establishment of linguistic economies of scale in higher education.

The elevation of Afrikaans to serve as a medium of instruction in higher education formed part of a broader process: the establishment of Afrikaans as an alternative form of cultural capital in the post-1910 unified political economy. In terms of the three manifestations of cultural capital outlined above, we can distinguish three conceptually distinct processes. The first was the contestation of physical and epistemological space within the higher education system. This was manifested in two ways: through the appropriation of space within existing Anglophone institutions and through the creation of new Afrikaans-medium institutions. These new institutions formed the basis of an Afrikaans sub-field of higher education and bilingualism played a significant role in the establishment of this sub-field. The University of South Africa was the only institution large enough to sustain parallel medium instruction - in the provision of distance education. At four institutions - Stellenbosch, Potchefstroom, Pretoria and the Orange Free State - dual medium instruction played a transitional role in the shift to monolingual Afrikaans instruction (du Plessis 2006).

With the appropriation of institutional space, the processes associated with the production of academic Afrikaans in material and embodied forms began. Once again, individual and institutional bilingualism played a significant role in both of these processes. The University of Port Elizabeth provides a particularly good case study of how this was achieved.

\section{Bilingualism at the University of Port Elizabeth}

In the years after 1918, institutional bilingualism emerged in the South African higher education system, where it served two distinct functions. Firstly, it 
institutionalized the political compromise reached by white English and Afrikaans speakers in 1910. Secondly, it provided Afrikaner nationalists with a means of developing Afrikaans as an alternative, but functionally equivalent medium in higher education. Formal institutional bilingualism - defined earlier in terms of a bilingual vocation and a stable bilingual infrastructure - was subsequently established at two universities: the University of South Africa and the University of Port Elizabeth. This similarity belies the fact that these two institutions were on opposite ends of an institutional continuum. Unisa is the oldest South African university and the institution in which the bilingual English-Afrikaans field had its inception. UPE was one of the last 'white' universities to be established and was the institution in which the limits, contradictions and fragility of the bilingual project were most vividly manifested.

The University of Port Elizabeth was established by an Act of Parliament on 31 January 1964. Established as a bilingual English-Afrikaans university, it was also from its inception a 'white' institution, established in terms of the apartheid higher education policy. The institutionalization of bilingualism at this university reflected the economic difficulties associated with the attempt to reconcile the linguistic and racial ideals of the ruling National Party. In 1959 the government promulgated the Extension of University Education Act (No. 45 of 1959), which provided the framework for racial demarcation in higher education. This Act defined most established universities as "white" and prepared the ground for the creation of "non-white" institutions. The new institutions were further subdivided to serve specific "ethnic groups", where ethnicity was operationalized in terms of race and language. Thus in the immediate aftermath of 1959 , Fort Hare - the only historically black university to antedate apartheid - was redefined as a "Xhosa institution" and three new "non-white" institutions were established: the University of Zululand, the University of the North and the University of the Western Cape.

In Port Elizabeth, demands for an Afrikaans medium higher education came into conflict with the broader Nationalist attempt to impose segregation on the system as a whole. The establishment of a bilingual institution was therefore based on a political compromise between white English and Afrikaans speakers in the region. The application was motivated in terms of the prevailing 'nation-building' project of the period. In a letter to the Mayor of Port Elizabeth, just prior to his interview with the Minister of Education, the former principal of the Rhodes PE Branch called for

an independent dual-medium university for Port Elizabeth. If we are going to make a success of this Republic we must bring the two white races together (cited in Rautenbach 1995: 101).

The decision to opt for a dual medium model reflected a recognition of economic constraints - the parallel medium option was considered too expensive. Between 1965 and 1975, when the University took possession of its new campus in Summerstrand, a unique language of tuition arrangement evolved. The dual medium model had three broad practical manifestations: 
- The duplication of all official documentation, which required the establishment of a translation service. During the early years the preponderance of Afrikaans speakers meant that the direction of translation was invariably from Afrikaans into English; ${ }^{8}$

- The alternation, on a yearly basis, of the two official languages at official gatherings;

- The allocation of each official language to specific disciplines for the purpose of instruction (Rautenbach 1995).

Dual medium instruction was the lynchpin of UPE's bilingual policy, the specifics of which were constantly revised in response to discipline and subject differentiation. Languages were allocated to specific disciplines, which meant that almost all first year students faced the possibility of having to enrol for classes where lectures would be presented in their second language. The language policy was therefore premised on a minimum bilingual proficiency in English and Afrikaans. Furthermore, from its inception an acquisitional imperative underpinned the language policy. There was, however, no formal provision for bilingual certification.

The dual medium model was unique among South African intuitions. The model nevertheless emerged within the context of a relatively developed bilingual higher education system, in which the parallel provision of higher education was sustained by distinct English and Afrikaans institutions. More generally it assumed the reproduction of demand for English and Afrikaans competencies and products in a white-dominated urban economy. This uniqueness was however also indicative of a certain fragility - to the extent that it was premised on a delicately maintained balance between the two languages at national level.

The primary motives that drove the initial push for bilingualism were: firstly, the desire to use Afrikaans to address the socioeconomic demands of working-class Afrikaners in Port Elizabeth; and secondly, once government approval had been secured, the desire to transcend the intra-white ethnnolinguistic conflict ${ }^{9}$ that had marked the university's inception. These regional Afrikaner goals were consonant with the broader Afrikaner nationalist programme of the 1950s and 1960s, which sought to elevate the status of Afrikaans relative to English in both the public and private sectors. References to "employer appreciation" in official publications of the time indicate the extent to which, by the late 1980s, UPE had come to play an important role in the elaboration of both regional and national markets for Afrikaans-English bilingualism. An important component of this was the mutually reinforcing

\footnotetext{
${ }^{8}$ Interview with respondent, conducted on Monday 20 October 2003 at the University of Port Elizabeth. The semi-structured interviews referred to in this article formed part of $\mathrm{PhD}$ fieldwork research (See Hill 2008).

${ }^{9}$ At UPE the internal mediation of the language conflict depended on the constant insulation of the campus from 'external' politics. This took the form of an unquestioning commitment to the Government's segregation policies and a concerted attempt to prevent any form of political mobilisation on campus - an increasingly prevalent trend on South African campuses during the 1970s and 1980s. From its inception the University prohibited the formation of student organisations affiliated to national political bodies or, for that matter, with any form of overt political agenda (see the student newspaper: Upen, 14 March 1991).
} 
relationship between the university and white schools throughout the Eastern Cape. White schools provided the certified minimum level of bilingual competence (matriculation exemption with both English and Afrikaans passed in the final year) required for university admission, while the University formed part of the broader process of economic and political differentiation that constituted the market for English-Afrikaans bilingualism.

Beginning in the early 1990 s, the negotiated transition at national level rapidly undermined the raison d'etre of the dual medium model. In August 1991 the University management held discussions with local members of the African National Congress (ANC) and the National Education Coordinating Committee (NECC). ${ }^{10}$ In June 1992 the Vice-chancellor made two significant announcements. Firstly, he claimed that, while the university placed a high premium on competence in both English and Afrikaans, a decision had been taken to shift from dual medium to parallel medium instruction - where numbers justified it. Secondly, the university had agreed to the compulsory admission of a certain percentage of applicants based on a test of potential. Whereas a matriculation exemption ${ }^{11}$ had traditionally been the minimum high school qualification required for university, the university had decided to adjust this policy, in order to allow access to a limited number of applicants without an exemption. Both of these measures were intended to facilitate access to African students, whose experience of Apartheid education and lack of competence in Afrikaans had continued to limit access to the University, even after the revocation of formal racial discrimination in 1989.

The attempt to make the University more reflective of the regional demography had immediate, but contrasting affects on language policy and practice. From the early 1970s UPE's language policy had taken the form of a detailed annual specification of the language medium for every course offered by the university. These specifications were contained in a section of the university's calendar, which was paginated in superscript and usually ran to more than 30 pages. In 1990 the detailed course specification was preceded by a brief description of the language policy, which had remained unchanged since the late 1970s. The section reads as follows:

Except for certain language subjects, all courses are presented through the medium of Afrikaans or English. Where a course is normally presented only in Afrikaans or only in English, but has to be duplicated owing to the size of the class, the language medium of the duplicated lectures will usually be in the other official language.

"A" denotes that the language medium is Afrikaans

"E" denotes that the language medium is English

\footnotetext{
10 The National Education Coordinating Committee (NECC) was established in December 1985 as an umbrella organisation seeking to coordinate community responses to the crisis in apartheid education. After 2000 it became closely associated with the education desk of the African National Congress and played an influential role in the formulation of new education policy initiatives (Soudien 1992)

${ }^{11}$ A matriculation exemption or 'matric' was the minimum standard, required for university entrance, in standard 10 (currently Grade 12) - the final year of formal schooling.
} 
"A+E" denotes that the language medium is partly Afrikaans and partly English

" $\mathrm{A}+\mathrm{N}$ " denotes that the language medium is partly Afrikaans and partly Nederlands

"D/G" denotes that the language medium is German

"F" denotes that the language medium is French ${ }^{12}$

This section remained unchanged in all calendars published between 1990 and 1993. The essence of the dual medium policy was contained in the specification that the overwhelming majority of courses be presented in either Afrikaans or English, which ruled out the need for duplication. Through the judicious monitoring of the whole university curriculum the overall balance between the two languages was maintained.

In June 1992 the Vice-Chancellor announced that the university would be shifting from dual medium to parallel medium instruction. He conceded that the duplication associated with this change would raise the cost of courses, but argued that this was justifiable as more students would complete their degrees. ${ }^{13}$ The motivation for this change was the desire to make the university more accessible to African students. African students in general, and isiXhosa speakers in particular, did not possess the required level of bilingual competence in English and Afrikaans, which put them at a decided disadvantage under the dual medium policy. There was, however, no serious attempt on the part of the university to implement parallel medium instruction. The first formal change in the language policy, as reflected in the calendar, came after the election of Jan Kirsten as Vice-Chancellor in October 1993. The following year the language policy section of the Calendar read as follows:

In 1993 the Council of the University approved a policy whereby all courses will eventually be presented partly in English and partly in Afrikaans. This policy will be phased in as follows:

1994 - all courses at first-year level

1995 - all courses at second-year level

1996 - all courses at third-year level

1997 - all other courses in the undergraduate programme, as well as LLB, B.Arch. and B.Ed. courses. ${ }^{14}$

A section on the practical implementation of the policy referred to the possibility of duplicating lectures "owing to the size of the class." All course material handed out to students would be in English and Afrikaans. Tests and examination papers would be in both languages and students would be entitled to answer papers in the language of their choice. This section is repeated in the calendars for 1996 and 1997. The superscripted section on dual medium instruction appears in the Calendars for 1994, 1995 and 1996. A superscripted section appears in the 1997 Calendar, but it contains no reference to medium of instruction. From 1998 the superscripted section

\footnotetext{
${ }^{12}$ Calendar, University of Port Elizabeth, 1990 , p. $71,72^{0-33}$.

${ }^{13}$ Upen, 4 August 1992.

${ }^{14}$ Calendar, University of Port Elizabeth, 1994, p. 72.
} 
disappears altogether. It is also worth noting that the list of UPE scholarship holders disappears from the Calendar in 1996. This scholarship had traditionally been awarded to final year students at white English and Afrikaans schools in the region.

The developments outlined above clearly do not constitute a shift to parallel medium instruction. The successful implementation of a parallel medium policy would have made considerable demands on the bilingual competence of staff members. Where duplication had taken place in the past, this had generally depended on the superior bilingual competence of Afrikaans speakers. As one longstanding member of staff noted, a minimum level of bilingual competence had in the past been a condition for both enrolment and employment at UPE.

[The bilingual policy] worked quite well while the University was still a whites-only institution... because it simply assumed unashamedly that the people who enter the university come from schools where they had to pass at least one of the two languages on the lower grade to get a matric [i.e. the second language]. Your student population was limited to whites; it was limited to people who came out of South African schools we were not concerned about internationals... it was thus assumed that they come here with a certain language competency, and that it was basic enough to build on and to develop further proficiency in their second language. And that worked quite well. Some of them actually thanked us for that; after a year or two they were quite proficient in the second language. ${ }^{15}$

The language policy implemented between 1994 and 1997 therefore represents an attempt to shore up the dual medium policy by delegating responsibility for implementation downwards, i.e. from faculties and departments to individual lecturers. On the supply side the plausibility of this policy was sustained by the bilingual capacities of most staff members. But the policy was undermined by the changing nature of demand. By the mid1990s, notwithstanding official protestations to the contrary, the value of the corporate bilingual model itself was increasingly subject to question. The primary reason for this was obvious - changing student demographics. The following chart provides a graphic representation of this shift between 1986 and 2002.

\footnotetext{
${ }^{15}$ Interview with respondent, conducted on Monday 20 October 2003 at the University of Port Elizabeth.
} 


\section{Figure 1: UPE enrolment trends by language $(1986-2002)^{16}$}

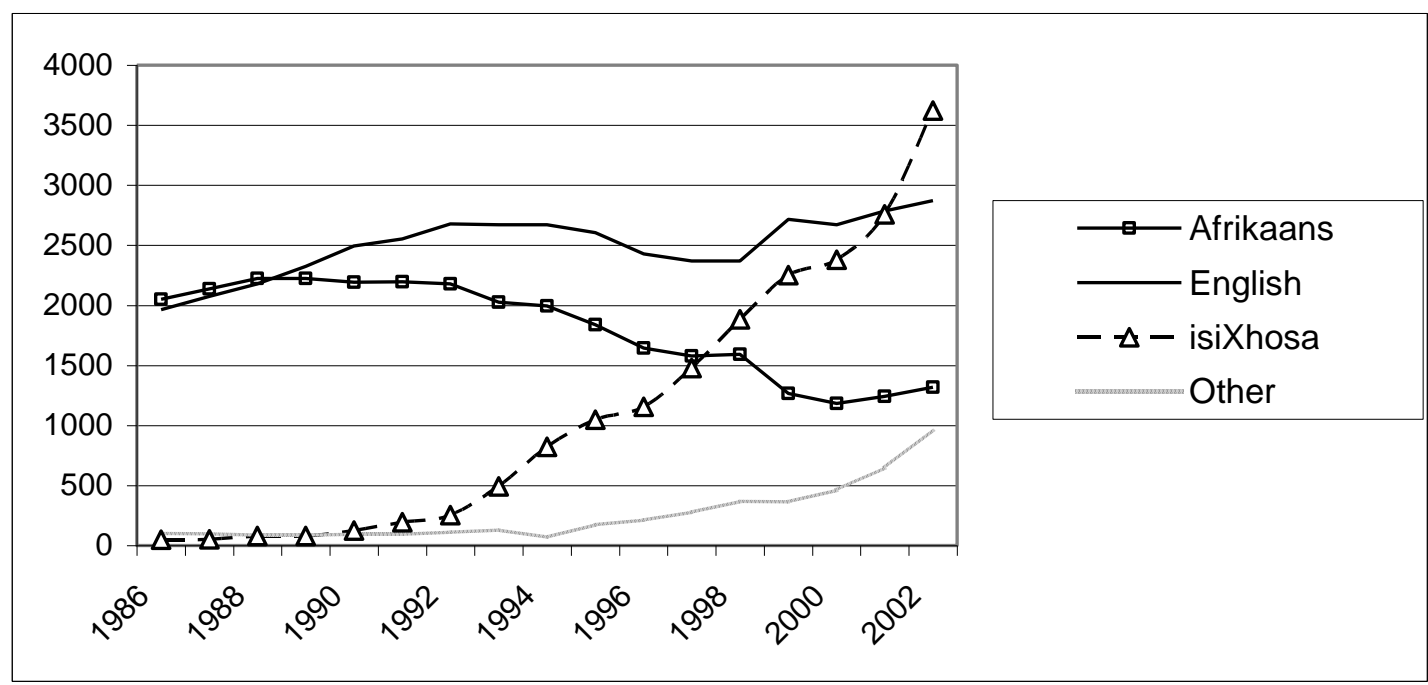

The English-Afrikaans bilingual tradition thrived in a context where white Afrikaans and English student enrolments were more or less equal. IsiXhosa speakers - despite being the largest regional ethnic group - were restricted to just $1 \%$ of the student population. The numbers of isiXhosa and other 'nonwhite' students were restricted in terms of the prevailing apartheid quota system of the period. After 1989 the quotas fell away and the isiXhosa speaking minority grew steadily. During the late 1990s the number of isiXhosa students surpassed that of white Afrikaans students (1997) and white English speakers (1998). During the mid-1990s the university administration therefore sought to balance the demands of two very different language constituencies: the Afrikaans-speaking demand for bilingual tuition; and the demand for English medium instruction from the growing number of isiXhosa and other students who did not have the requisite passive command of Afrikaans. In this process the rapid decline of Afrikaans as an institutionalized medium was to some extent offset by the embodied bilingual capacity of white staff members and students. Policy pronouncements therefore tended to mask the changing pattern of language practices at the University. In doing so, they nevertheless also reflected the emergence of a new official discourse on 'multilingualism' at national level.

\section{Multilingualism and the decline of the bilingual field of higher education}

The University of Port Elizabeth provides an interesting case study of an 'organic' shift away from institutional bilingualism. The process was organic in the sense that it was driven by changes in the external environment and to the extent that policy pronouncements tended to belie or lag behind actual language practices. In this final section I explore a crucial aspect of this external environment - the emergence of official discourse and policies on 'multilingualism' at national level.

\footnotetext{
${ }^{16}$ The table is based on enrolment data obtained from the South African Department of Education.
} 
In the previous section I noted the peculiar 'decision' made by the University's vice chancellor in 1992 to replace the dual medium model with a form of parallel medium instruction. At UPE this announcement was not followed up in any substantial way, but the declaration did accord with similar decisions and institutional changes made at a number of Afrikaans universities. During the 1990s parallel medium instruction was introduced at the University of Pretoria, the University of the Free State and the Rand Afrikaans University. ${ }^{17}$ Given the widespread recognition earlier in the century that parallel medium universities were too expensive to maintain, how does one explain the rapid shift to parallel medium instruction among Afrikaans universities in the 1990s? The answer lies in an examination of the changing status of Afrikaans, both as an academic medium at university level and more generally as a form of cultural capital in post-apartheid South Africa.

At UPE the shift to 'parallel medium' instruction, initially, and 'multilingualism', subsequently, occurred principally at the level of official discourse. Beyond what one might term 'set piece multilingualism ${ }^{18}$, this new discourse was not matched by a concrete commitment to a new model of bilingual or multilingual instruction. While tacitly recognising the unsustainability of the dual medium model, a series of new policies also tended to mask the de facto Anglicization of the institution. The policies therefore reflected a legitimating institutional discourse, which drew inspiration from a similar policy making process at national level. Academics drawn from education, languages and linguistics have tended to be the main proponents of multilingualism at national level, and this is also evident at UPE. The visit of Neville Alexander - convener and chairperson of the National Commission on Higher Education's Language Policy Working Group ${ }^{19}$ - in 1997 provided the initial stimulus for the development of this new discourse at UPE. The national discourse on multilingualism in higher education was formalized in a number of official documents, which include the National Plan for Higher Education (2001) and the Language Policy for Higher Education (2002). This discourse reflects sensitivity to the fact that English and Afrikaans remain the only languages that function as academic media in South Africa. Moreover, the rapid post1994 decline in the academic status of Afrikaans has not been matched by any appreciable change in the status of the indigenous African languages.

The actual shift to parallel medium instruction at a number of Afrikaans universities - notable those situated in the major urban centres of Johannesburg, Pretoria and Bloemfontein - represented a response to the same basic external pressures evident in the UPE case. Trends evident in Port Elizabeth therefore form part of a broader national pattern - a relative decline in the status of Afrikaans as both a medium of instruction in higher

\footnotetext{
${ }^{17}$ Following the institutional mergers of 2002-5 this university became part of the University of Johannesburg.

${ }_{18}$ Examples of set piece multilingualism at UPE include trilingual signage and the use of Engish, Afrikaans and isiXhosa at official functions.

19 "Towards a National Language Plan for South Africa" - final report of the Language Plan Task Group (LANGTAG), Department of Arts, Culture, Science and Technology, 1996.
} 
education and, more generally, as a form of academic cultural capital. This trend can be disaggregated in terms of the three broad manifestations of cultural capital outlined above.

Within the sphere of higher education Afrikaans has been sustained most obviously in the form of the embodied capacities and dispositions of first language English and Afrikaans speakers. On the supply side the academic teaching staff at most urban South African universities comprise mostly white English-Afrikaans bilinguals. While Afrikaans speakers tend to be far more bilingual than their Anglophone counterparts, the more passive Afrikaans capacities of white English speakers have played a significant role in sustaining the academic status of Afrikaans. On the demand side, Afrikaans at UPE and traditionally Afrikaans institutions of higher learning was sustained by the demand for Afrikaans tertiary education among students graduating from Afrikaans medium high schools. White English speakers also constituted a market for the language, given that a matric-level qualification in Afrikaans was a condition for university entrance. As the beneficiaries of apartheid education, white English and Afrikaans speakers have tended to share both a minimum level of bilingual competence and a more-or-less positive set of dispositions towards the two official languages. The status that Afrikaans has traditionally enjoyed in higher education can therefore be explained both in terms of formal policies and the socially situated bilingual capacities of 'middle class' white South Africans. White English and Afrikaans speakers have therefore traditionally shared both a mutual capacity to understand each other and the stock of attitudes / dispositions associated with a bilingual habitus. ${ }^{20}$

Afrikaans has also been sustained as a relatively powerful objectified medium in South Africa, although the situation in higher education is more tenuous that in other domains. There has been a dramatic decline in the quantity and range of academic publication in Afrikaans since 1994. The wholesale disappearance of bilingual journals has to some extent been compensated by the growth of an active academic presence on the Internet. Afrikaans nevertheless maintains a powerful position vis-à-vis the indigenous African languages in terms of a more general manifestation of cultural materials, e.g. newspapers, popular books, CDs etc. ${ }^{21}$

The changing status of academic Afrikaans - and by extension academic bilingualism - has been most obvious in the rapid decline Afrikaans as a form of institutionalized cultural capital. Faced with demands for transformation and the growing recognition that English is the only viable lingua franca among African students, Afrikaans academics quickly came to accept that Afrikaans universities were over-represented within the higher education

\footnotetext{
20 The concept of habitus derives from Leibniz. In sociology the concept is most closely associated with the work of Norbert Elias and Pierre Bourdieu. Bourdieu (1999) defines habitus as follows: "The practices of the members of the same group or, in a differentiated society, the same class, are always more and better harmonized than the agents know or wish... The habitus is precisely this immanent law, lex insita, inscribed in bodies by identical histories, which is the precondition not only for the co-ordination of practices but also for practices of co-ordination."

${ }^{21}$ According to the Afrikaans indexing site, Die Knoop (www.dieknoop.co.za), Afrikaans speakers account for about $40 \%$ of disposable income in South Africa.
} 
system. Du Plessis (2006) argues that bilingual education is currently the "only legal framework within which Afrikaans may be retained as a medium of higher education." This is true, to the extent that the national ministry of education has rejected the notion of an 'Afrikaans university.'

The Ministry is also concerned that some individuals have equated institutional responsibility for promoting Afrikaans as an academic medium to the establishment of 'Afrikaans' universities. The notion of Afrikaans universities runs counter to the end goal of a transformed higher education system, which as indicated in the National Plan for Higher Education (NPHE), is the creation of higher education institutions whose identity and cultural orientation is neither black nor white, English or Afrikaans speaking, but unabashedly and unashamedly South African. ${ }^{22}$

This statement effectively rejected an earlier proposal by the Government appointed Gerwel Commission ${ }^{23}$ that two universities (Stellenbosch and Potchefstroom), each situated in predominantly Afrikaans regions, be designated as the custodians of academic Afrikaans. Thus, although the Ministry has expressed a commitment to defending the status of Afrikaans as an academic language, it has rejected the principles of linguistic territoriality ${ }^{24}$ and institutional responsibility for language development. The decline of Afrikaans as a form of institutionalized cultural capital is therefore most obviously manifested in the rejection of the idea of a 'language vocation' for specific institutions. Government opposition to this idea is very strong, but equally significant has been the growth of opposition within the Afrikaans academic community. ${ }^{25}$

Within the market for Afrikaans medium higher education there were other important institutional factors influencing the academic status of the language. White Afrikaans speakers - like their English speaking counterparts - are relatively wealthy, predominantly urbanised and therefore widely distributed throughout South Africa. Under conditions of growing scarcity, the product of declining subsidies and the growing enrolment of non-Afrikaans speakers, the perceived language-specific needs of Afrikaans speakers in the national context are therefore undercut by vested institutional interests at local level. In the context of a national decline in the enrolment of Afrikaans speakers, parallel medium instruction was presented by many as a means of defending Afrikaans in disparate regions, while simultaneously extending access to previously denied students.

\footnotetext{
${ }^{22}$ Language Policy for Higher Education, Ministry of Education, November 2002, sections 15.4.3.

${ }^{23}$ Report on the position of Afrikaans in the University System, informal committee chaired by Prof. G.J. Gerwel, 14 January 2002.

${ }^{24}$ Langner and Imbach (2000) explore this concept in the Swiss higher education context.

${ }^{25}$ One noteworthy example is the criticism levelled against the notion of an 'Afrikaans university' by the former vice chancellor of the University of Stellenbosch, Chris Brink. Brink associates this notion with a call for "a cordon sanitaire around Afrikaans as undergraduate medium of instruction [with] no contamination from the English virus being allowed" (Brink 2006).
} 
This argument has been countered by those who feel that parallel medium instruction is simply unsustainable - notably historian Hermann Giliomee and other academics at the University of Stellenbosch. Citing the work of the French-Canadian linguist, J.A. Laponce (1987), Giliomee (2001) has argued that in a context where English is increasingly the dominant public sector language, the shift to parallel medium instruction will prove to be a transitional phase en route to complete Anglicisation. In 1998 Giliomee formed a consultation forum, based on a Belgian model, called the Afrikaanse Oorlegplatform (Afrikaans Consultation Platform). Under the banner of this organisation a number of discussions were held on the future of Afrikaans as an academic language. From an analysis of these discussions it becomes clear that the debate on parallel medium instruction reflects the contrasting positions of the different Afrikaans universities within the changing bilingual field of higher education. The dilemma facing Afrikaans universities was well summarized by one of the delegates attending a meeting organised by this forum.

I am somewhat confused as to whether we are speaking about the survival of universities or the survival of Afrikaans. I think issues that concern the survival of a particular university, differ from those that have to do with the survival of Afrikaans as a language, and in this respect I would say that a university is one of the possible structures that can facilitate the survival of the language. ${ }^{26}$

Set against the background of major inequalities in South African higher education and - after 2000 - the dramatic restructuring of the field of higher education, there was no consensus among Afrikaans universities on how to resolve this issue. ${ }^{27} \mathrm{At}$ the heart of the debate on the merits of parallel medium instruction lie contending vested interests in the shrinking market for Afrikaans higher education. This shrinking market has manifested itself in new forms of bilingualism at the level of specific institutions, but the sustainability of these remains to be demonstrated.

The decline of bilingualism at the University of Port Elizabeth would seem to confirm a more general characteristic of bilingual universities: their dependence on a wider political compromise between two language communities. ${ }^{28}$ Moreover, this compromise is usually manifested as a form of

\footnotetext{
${ }^{26}$ F. van Zyl slabbert, at a discussion on the future of Afrikaans at historically Afrikaans universities, organised by the Afrikaanse Oorlegplatform (Afrikaans Consultation Forum) at Oude Libertas, Stellenbosch, 14 March 1999 - extracted from the forum transcript (my translation).

${ }^{27}$ Similarly, the organisation representing the rectors of the Historically Afrikaans Universitities (HAUs) opposed the idea that responsibility for Afrikaans should be vested in a reduced number of institutions. See Language Policy for Higher Education, Ministry of Education, November 2002, sections 15.4.2.

${ }^{28}$ This compromise tends to be indicated most clearly in the titles of bilingual universities: Fribourg / Freiburg; Bozen / Bolzano; NUI Galway / OÉ Gaillimh; Prifysgol Aberystwyth / Aberystwyth University; Université d'Ottawa / University of Ottawa. In South Africa I would include Stellenbosch University / Universiteit Stellenbosch in this category, where the language compromise is (controversially) sustained by the demography and politics of the Western Cape Province.
} 
institutionalized capital at national or regional government level and is sustained by a political economy in which the 'parallel' reproduction of formal sector demand for the languages is guaranteed. Higher education systems draw on complex transnational fields of knowledge and applied research. Bilingual universities are therefore expensive in two distinct senses: firstly, they assume the availability of material resources to reproduce bilingual institutional spaces and to supply academic fields in two languages; and secondly, they require the cultural capacity to develop and sustain demand for a language as a form of cultural capital in a stratified political economy. In South Africa the bilingual compact at national level has been superseded by a formal commitment to develop eleven official languages. This official position nevertheless belies the growing status of English in the formal sectors of the state and the economy. To the extent that the decline of Afrikaans at UPE (and, since 2005, the Nelson Mandela Metropolitan University) has not been matched by a corresponding increase in the formal use of isiXhosa, the case study is indicative of a broader trend: the Anglicisation of South African higher education. This, I would argue, corresponds with an even more general pattern: the growing international status of English in higher education and the concomitant difficulty associated with the development of new tertiary-level media of instruction in developing countries.

\section{Conclusion}

Dual medium higher education at the University of Port Elizabeth traces its origins to an Afrikaans initiative in the 1960s - a time when Afrikaans had recently been established as a medium of tertiary instruction at a number of other institutions. While UPE was instrumental in extending the Afrikaans subfield of higher education into the Eastern Cape, social and economic constraints dictated that this could only be achieved by means of a bilingual institution. At this time parallel medium instruction was widely considered to be too expensive and the choice of a dual medium model therefore assumed an English-Afrikaans bilingual capacity as a condition of enrolment. The establishment of the University also formed part of the government's attempt to extent apartheid to the higher education system. The main social cost of the dual medium model was therefore the exclusion of black students - and notably isiXhosa speaking students. Even after the revocation of formal racial exclusion, the bilingualism condition effectively excluded most isiXhosa speakers. Beginning in the early 1990s, the University's decision to break with its racist past and enrol previously excluded students undermined the raison d'etre of the dual medium model.

The rapid decline of numerous practices that had traditionally been associated with institutional bilingualism at UPE was not preceded by any clear alternative policy formulation. From the initial announcement of a shift to 'parallel medium instruction' to subsequent policy commitments to 'multilingualism', post-1990 policy development was reactive and tended to mask the actual shift to English medium instruction. The primary reasons for this shift were political pressure and the changing demography of enrolment. By 1997 isiXhosa students outnumbered Afrikaans students and the demand for dual medium instruction had effectively disappeared. Given the large number of bilingual English and Afrikaans staff members, a residual capacity 
to supply bilingual instruction partially explains the policy lag at this time. Multilingual policies at UPE - and its successor institution, the Nelson Mandela Metropolitan University - are clearly also derived from national policy and a new official discourse on multilingualism at national level. This new discourse was formalized after 2000, but the details - manifested in specific 'language plans' - have been left to individual institutions. At national level an implicit, but diffuse, commitment to institutional bilingualism can be inferred from a general commitment to 'multilingualism' and a more specific opposition to the idea of an Afrikaans university. The decline of the dual medium model at UPE therefore forms part of a broader national trend: the decline of Afrikaans - relative to English - as a medium of instruction at all institutions where the language was previously used; and a more general decline of Afrikaans and English-Afrikaans bilingualism as forms of cultural capital within an increasingly monolingual field of higher education.

This article began with a conceptual distinction between 'bilingual' and 'multilingual' universities. Based on recent contributions to a relatively small literature on bilingual universities, I adopted a relatively strong definition of the bilingual university: an institution in which a normative commitment to developing and sustaining two languages as academic media is accompanied by relatively stable bilingual teaching infrastructure. Two institutional forms are commonly referred to in the literature: parallel medium and dual medium instruction. I noted the relative rarity of this type of institution. Bilingual universities are rare when compared to monolingual universities and even more so when compared to the growing number of institutions in which two or more languages are used in a vertical division of labour - and where English typically predominates at postgraduate level. Numerous writers have noted that bilingual universities have their origins in a wider political project. They tend to reflect a national compromise, which is expressed in terms of a commitment to sustaining two languages as functionally equivalent media in higher education. The case study explored here conforms with this trend and, moreover, demonstrates how quickly a bilingual model may decline once the broader political context that sustained it is transformed. Aspects of the regional and national political economies in which these changes occurred are unique - notably the particular legacy of racial exclusion and inequality that South African universities are struggling to overcome.

The case study nevertheless also raises the question as to which characteristics may more generally be attributed to bilingual universities. I would argue that the relative rarity of these institutions - along with the predominance of Indo-European languages - is indicative of the elite status of the political compromises that underpin them. To what extent are bilingual universities in general founded on the relatively expensive reproduction of bilingual institutions and bilingual habitus identified in this case study? It would seem that a more general comparative study of these institutions must move beyond the acknowledgement of the regional and national political compromises on which they are based to explore a more general pattern of linguistic path dependence in global higher education. Here I refer to the relative lack of bilingual universities - narrowly defined - in developing countries, as well as the predominance of European languages in institutions 
that meet these criteria. This case study has hopefully provided an interesting instantiation of an approach that will be conducive to more general comparative research. 


\section{References}

Anckar, Olle (2000). University Education in a Bilingual Country: the Case of Finland. Higher Education in Europe XXV, 499-506.

Beillard, Jean-Michel (2000). Bilingualism in a Canadian Context: The Case of the University of Ottawa. Higher Education in Europe XXV, 469-476.

Boucher, Maurice (1973). Spes in arduis: a history of the University of South Africa. Pretoria: University of South Africa.

Bourdieu, Pierre (1986). The Forms of Capital. In John G. Richardson (ed.), Handbook of Theory and Research for the Sociology of Education New York: Greenwood Press.

Bourdieu, Pierre (1991). Language and symbolic power. Cambridge: Polity Press.

Bourdieu, Pierre (1999). Structures, Habitus, Practices. In Anthony Elliott (ed.), Blackwell Reader in Contemporary Social Theory Malden: Blackwell.

Brink, Chris (2006). No Lesser Place - The taaldebate at Stellenbosch. Stellenbosch: Sun Press.

du Plessis, Theo (2006). From monolingual to bilingual higher education: the repositioning of historically Afrikaans-medium universities in South Africa. Language Policy 5, 87-113.

Giliomee, Hermann (2001). Die taal- en kulturele uitdagings van die histories Afrikaans universiteite. In Hermann Giliomee and Lawrence Schlemmer (eds.), Kruispad - Die toekoms van Afrikaans as openbare taal Cape Town: Tafelberg.

Hartshorne, K.B. (1987). Language Policy in African education in South Africa, 1910-1985, with particular reference to the issue of medium of instruction. In Douglas Young (ed.), Bridging the gap between theory and practice in English second language teaching Cape Town: Maskew Miller Longman.

Haugen, Einar (1983). The implementation of corpus planning: theory and practice. In Juan Cobarrubias and Joshua A. Fishman (eds.), Progress in Language Planning: International Perspectives 269-289. Berlin: Mouton.

Hill, Lloyd (2008). Language and Higher Education in South Africa, PhD thesis, University of Warwick.

Jernudd, Björn H. (2002). Managing languages at bilingual universities: relationships between universities and their language environment. In Li Wei, Jean-Marc Dewaele and Alex Housen (eds.), Opportunities and Challenges of Bilingualism 297-310. Berlin: Mouton de Gruyter. 
Langner, Michael and Imbach, Ruedi (2000). The University of Freiburg. Higher Education in Europe XXV, 461-509.

Laponce, JA (1987). Languages and Their Territories. Toronto: University of Toronto Press.

Purser, Lewis (2000). The Bilingual University - General Reflections on its Origins, Mission, and Functioning. Higher Education in Europe XXV, 452-459.

Rautenbach, Theodorus Cornelius (1995). Die stigting en aanvangsjare van die Universiteit van Port Elizabeth. Department of History Port Elizabeth: University of Port Elizabeth.

Scholtz, G.D. (1984). Die Ontwikkeling van die Politieke Denke van die Afrikaner: 1939-1948. Perskor.

Swartz, David (1997). Culture and Power - The Sociology of Pierre Boudieu. Chicago: University of Chicago Press.

van der Walt, Christa and Brink, Chris (2005). Multilingual universities: a national and international overview. SA Journal for Higher Education $19,822-852$.

Wacqant, Loïc J. D. (1989). Forward. In Pierre Bourdieu (ed.), The State Nobility - Elite Schools in the Field of Power Stanford: Stanford University Press. 